\title{
EXPLORING THE FUNCTIONAL DOMAIN AND THE TARGET OF THE TETANUS TOXIN LIGHT CHAIN IN NEUROHYPOPHYSIAL TERMINALS
}

\author{
G. Dayanithi,* B. Stecher, $\dagger \|$ B. Höhne-Zell, $\uparrow$ S. Yamasaki, $\ddagger$ T. Binz, $\ddagger$ U. Weller, $\S$ \\ H. NiEmann $\ddagger$ and M. Gratzl $\dagger^{\dagger}$ \\ *Laboratoire de Neurobiologie Endocrinologique URA 1197, CNRS, Université Montpellier-2, \\ Place Eugène Bataillon, F-34095 Montpellier-cedex 5, France \\ †Abteilung Anatomie und Zellbiologie, Universität Ulm, D-89069 Ulm, Germany \\ łBundesforschungsanstalt für Viruskrankheiten der Tiere, Tübingen, Germany \\ §Institut für Medizinische Mikrobiologie, Universität Mainz, Germany
}

\begin{abstract}
The tetanus toxin light chain blocks calcium induced vasopressin release from neurohypophysial nerve terminals. Here we show that histidine residue 233 within the putative zinc binding motif of the tetanus toxin light chain is essential for the inhibition of exocytosis, in the rat. The zinc chelating agent dipicolinic acid as well as captopril, an inhibitor of zinc-dependent peptidases, counteract the effect of the neurotoxin. Synthetic peptides, the sequences of which correspond to motifs present in the cytoplasmic domain of the synaptic vesicle membrane protein synaptobrevin 1 and 2 , prevent the effect of the tetanus toxin light chain.

Our results indicate that zinc bound to the zinc binding motif constitutes the active site of the tetanus toxin light chain. Moreover they suggest that cleavage of synaptobrevin by the neurotoxin causes the inhibition of exocytotic release of vasopressin from secretory granules.
\end{abstract}

Neurons and endocrine cells release their secretory products by regulated exocytosis. Release of the contents of secretory granules and synaptic vesicles from neurons and endocrine cells is highly regulated by calcium. However, the precise mechanism of calcium triggered fusion of secretory vesicles with the plasma membrane is still poorly understood.

The use of cells, synaptosomes and neurosecretosomes which have had their plasma membrane permeabilized, thereby allowing passage of exogenous molecules, has been instrumental in the establishment of the regulatory effect of intracellular calcium and its modulation by a variety of substances (including cAMP, GTP, ATP, diacylglycerol and others). Permeabilization of cells also facilitated the analysis of the basic mechanisms underlying the inhibition of exocytosis by clostridial neurotoxins such as tetanus and botulinum toxins: previous experiments have shown that the disulfide linked light and heavy chains of clostridial neurotoxins must be separated before the light chain, which harbors the active domain, can block calcium-evoked exocytosis by endocrine cells. ${ }^{1,2,-10,49,51}$ Similarly injection into

|Present address: Lehrstuhl für Entwicklungsneurobiologie, Fakultät für Biologie, Universität Konstanz, Germany. Abbreviations: DPA, dipicolinic acid; DTT, dithiothreitol; EDTA, ethylenediaminetetra-acetate; EGTA, ethyleneglycol bis $(\beta$-aminoethylether $) N$, $N^{\prime}$-tetra-acetate; HEPES, $N$-2-hydroxyethylpiperazine- $N^{\prime}$-2-ethanesulfonic acid; PIPES, piperazine- $N, N^{\prime}$-bis(2-ethanesulfonic acid); TeTxL, tetanus toxin light chain; WT, wild type.
Aplysia neurons, of either the light chain itself or of mRNA encoding the toxin ${ }^{31,37,38}$ inhibits exocytosis as does introduction of the light chains into mammalian cortical and neurohypophysial nerve terminals. ${ }^{16,18.50}$

Recently it has been reported that incubation of isolated synaptic vesicles with tetanus toxin results in the cleavage of the synaptic vesicle membrane protein synaptobrevin..$^{43,44}$ Furthermore, inhibition of glutamate release from cortical synaptosomes by tetanus toxin was paralleled by cleavage of synaptobrevin ${ }^{32}$ whilst blockage of acetylcholine release from Aplysia neurons injected with tetanus toxin was delayed by peptides corresponding to the proposed synaptobrevin 2 cleavage site. ${ }^{43}$ Transglutaminase activated by tetanus toxin covalently modifies synapsin I suggesting that synapsin I could also be a target of the neurotoxin. ${ }^{2122}$ Taken together these observations indicate that the inhibition of neurotransmitter release from synaptic vesicles by the tetanus toxin light chain may be causally linked to the cleavage or covalent modification of synaptic vesicle proteins.

The molecular structure and the sequence of most clostridial neurotoxins is known. ${ }^{40}$ The light chains of tetanus toxin and botulinum $A$ toxin contain a motif (HELIH, position 233-237) which is also present in a variety of zinc-dependent peptidases. ${ }^{30}$ Both tetanus and botulinum $A$ toxin bind one atom of zinc per molecule $44,45,59$ suggesting that the neurotoxins are zinc peptidases. 
Release of transmitters or hormones by neurons and endocrine cells may occur from at least two different types of secretory organelles. One type, containing primarily amines and/or peptides, is characterized by an electron dense core (hence the term dense core vesicles, or secretory granules), whilst the second type, which is translucent and filled with classical neurotransmitters, when present in neurons, is referred to as synaptic vesicles. Clostridial neurotoxin light chains also inhibit exocytotic release of secretory granules ${ }^{1,2,8-10,16,18,49-51}$ but it is not clear whether zinc, and the zinc binding motif within the light chain of tetanus toxin, are essential for the inhibition of secretory granule exocytosis.

In the present study we used isolated neurohypophysial nerve endings as a model system to examine the function of the tetanus toxin light chain. In these nerve endings vasopressin is released from secretory granules. Exocytotic release of vasopressin from permeabilized neurohypophysial nerve endings can be blocked by botulinum $\mathrm{A}$ and tetanus toxin light chains. ${ }^{16,18}$ If these toxins act as metallopeptidases, then we would anticipate removal of the metal cofactor (zinc), addition of captopril, a specific inhibitor of zinc peptidase activity ${ }^{11,15}$ or mutational modification of the proposed zinc binding motif to abolish its action. Similarly we propose that co-incubation of permeabilized neurosecretosomes with synthetic peptides corresponding to the putative cleavage site of synaptobrevin 2 should competitively inhibit the action of clostridial neurotoxins, if synaptobrevin rather than synapsin $I$ is a target of the tetanus toxin light chain in neurohypophysial terminals.

\section{EXPERIMENTAL PROCEDURES}

\section{Isolation of neurosecretory nerve terminals}

Neurointermediate lobes were removed from the male Wistar rats (Charles River, Sulzfeld, Germany) of 250-300 g body weight, washed with Locke saline containing (in $\mathrm{mM}$ ) $\mathrm{NaCl}$ (140), $\mathrm{KHCO}_{3}$ (5), $\mathrm{MgCl}_{2}$ (1), $\mathrm{CaCl}_{2}$ (2.2), HEPES (10), $\mathrm{pH} 7.2$, glucose (10), and $0.025 \%$ bovine serum albumin (Sigma, Munich, Germany). Throughout the isolation procedure the temperature was maintained at $37^{\circ} \mathrm{C}$. Four neural lobes were gently homogenized by hand using a loose-fitting Teflon-to-glass homogenizer in $1 \mathrm{ml}$ medium containing $270 \mathrm{mM}$ sucrose, $10 \mathrm{mM}$ HEPES (pH 7.2) and $2 \mathrm{mM}$ EGTA. The osmolarity of the media was maintained between 300 and $310 \mathrm{mosmol} / \mathrm{kg}$. The nerve endings were then isolated as described. ${ }^{13}$ Briefly, the homogenate was centrifuged at $100 \mathrm{~g}$ for $1 \mathrm{~min}$, and the resulting supernatant was further centrifuged at $2400 \mathrm{~g}$ for $4 \mathrm{~min}$. The resulting pellet, containing mostly nerve endings, as judged by electron microscopy, ${ }^{41}$ was resuspended in Locke saline and loaded onto eight $0.45 \mu \mathrm{m}$ filters (Acrodisc LC 13, Gelman Sciences, Dreieich, Germany).

Permeabilization of the nerve terminals and measurement of vasopressin release

The nerve terminals on the filters were perifused at $37^{\circ} \mathrm{C}$ by means of a multichannel peristaltic pump (Ismatec IPN-8, Zürich, Switzerland) for $45 \mathrm{~min}$ with Locke saline at a flow rate of $50 \mu 1 / \mathrm{min}$. Subsequently the terminals were perifused (flow $100 \mu 1 / \mathrm{min}$ ) for $10 \mathrm{~min}$ with Locke saline containing $2 \mathrm{mM}$ EGTA instead of calcium and then for
45 min with potassium glutamate medium (hereafter defined as medium B containing (in $\mathrm{mM}$ ) potassium glutamate (150), magnesium acetate (7.0), EDTA (5), EGTA (0.5), PIPES (10), pH 6.8. This medium, used in all subsequent steps as a surrogate for the intracellular fluid, contains $2 \mathrm{mM}$ free $\mathrm{Mg}^{2+}$, which is optimal for the study of exocytosis in permeabilized chromaffin cells and neurohypophysial nerve terminals. ${ }^{17,55}$ For permeabilization, the nerve terminals were perifused (flow $100 \mu \mathrm{l} / \mathrm{min}$ ) for $5 \mathrm{~min}$ with streptolysin $\mathrm{O}(50$ hemolytic units $/ \mathrm{ml})$ in medium B containing $1 \mathrm{mM}$ dithiothreitol (DTT) as a reducing agent. Subsequently, the terminals were perifused for $30 \mathrm{~min}$ (pump speed was reduced to minimum flow of approximately $15 \mu 1 / \mathrm{min}$ in order to economize the toxin materials used) with tetanus toxin light chain or different recombinants dissolved in medium B or with medium B alone (controls). The nerve terminals were then perifused (flow $100 \mu \mathrm{l} / \mathrm{min}$ ) for $4 \mathrm{~min}$ with medium $B$ before collection of the fractions.

In some experiments tetanus toxin light chains (TeTxLs) $\left(100 \mathrm{nM}\right.$ ) were preincubated for 30 min at $4^{\circ} \mathrm{C}$ in medium $\mathrm{B}$ with $100 \mu \mathrm{M}$ dipicolinic acid (Sigma, Munich, Germany), $1 \mathrm{mM}$ captopril (Bristol-Myers Squibb, Regensburg, Germany), $100 \mu \mathrm{M}$ sodium diethyldithiocarbamate (Merck, Darmstadt, Germany) or $100 \mu \mathrm{M}$ synthetic peptides followed by $5 \mathrm{~min}$ at $37^{\circ} \mathrm{C}$ and then exposed to the nerve terminals.

Fractions of the perifusate were collected every $2 \mathrm{~min}$ by means of a microfraction collector (model 203, Gilson medical Electronics, Villiers le Bel, France) and immediately frozen until radioimmunoassay for arginine-vasopressin was performed. ${ }^{12}$ Vasopressin release was triggered after $16 \mathrm{~min}$ by challenging the nerve endings with medium $B$ supplemented with $10 \mu \mathrm{M}$ free $\mathrm{Ca}^{2+}$. Free $\mathrm{Ca}^{2+}$ concentrations were calculated and controlled with a $\mathrm{Ca}^{2+}$ specific electrode as described recently. ${ }^{24}$ In order to assure the response of the permeabilized nerve endings to $\mathrm{Ca}^{2+}$ and the TeTxL their effects were checked in each group of experiments (see Figures presented in this paper).

\section{Tetanus toxin light chains, streptolysin $O$ and peptides}

The expression of recombinant light chains of tetanus toxin in E. coli strain M15 using a newly synthesized gene ${ }^{19}$ encoding the entire light chain with six $\mathrm{C}$-terminally added H-residues will be published elsewhere (Niemann et al. unpublished observations). Mutants were generated by replacement of a SnaBI-Fphl restriction fragment ${ }^{19}$ with suitable synthetic oligonucleotides. All mutants were characterized by DNA sequencing using the chain termination method. ${ }^{42}$ The protein was purified from the bacterial lysates on a Ni-agarose column. Recombinant light chain (wild type, WT), recombinants in which histidine (position 233) was replaced by cysteine or valine (mutants $\mathrm{H}^{233} \mathrm{C}$, or $\mathrm{H}^{233} \mathrm{~V}$ ) were used in this study.

Natural tetanus toxin was isolated and characterized as previously described. ${ }^{28,57}$ During toxin purification, EDTA ( $4 \mathrm{mM}$ ) was present in the first column step (HIC). Tetanus toxin was separated into its heavy and light chains by isoelectric focusing in a sucrose gradient with ampholyte under reducing conditions in $2 \mathrm{~mol} . / 1$ urea. ${ }^{56}$ Before use in the purified TeTxL preparations were dialysed against medium B. Prior to zinc determination TeTxL was incubated for $5 \mathrm{~min}$ at $30^{\circ} \mathrm{C}$ in medium $\mathrm{B}$ or in medium $\mathrm{B}$ containing $100 \mu \mathrm{M}$ dipicolinic acid (DPA). After concentration of the protein by centrifugation for $10 \mathrm{~min}$ at $7000 \mathrm{~g}$ in a Centricon MG 30,000 device (Amicon, Witten, Germany) medium B (or medium B containing $100 \mu \mathrm{M}$ DPA) was added, centrifuged as above, and zinc was determined in the concentrate by atomic absorption spectroscopy (Zeemann-AAS 4100 ZI, Perkin-Elmer, Uberlingen, Germany).

Streptolysin O was purified from group A streptococci (Richards strain) by SH-specific chromatography followed 
by HIC chromatography (Weller et al., unpublished observation).

The peptides QFET, ASQFETS as well as the 20-mers DALQAGASVFESSAAKLKRK (peptide 1) and DALQAGASQFETSAAKLKRK (peptide 2) were prepared by solid phase synthesis using an automatic synthesizer (431A, Applied Biosystems, Foster City CA, U.S.A.) employing Fmoc chemistry. The products were detached from the resin with trifluoroacetic acid (Sigma) and purified by reversedphase HPLC. The peptides were characterized by Edman sequencing on a model 473A sequencer (Applied Biosystems, Foster City CA, U.S.A.).

\section{RESULTS}

Isolated, streptolysin O-permeabilized nerve terminals perifused in the absence of calcium, released only low and constant amounts of vasopressin (Fig. 1). However, addition of $10 \mu \mathrm{M}$ free calcium caused a several-fold increase in vasopressin release (Fig. 1, control). The sum of vasopressin released during the 16 min following the elevation of $\mathrm{Ca}^{2+}$ in the medium was approximately four-fold higher when compared with the vasopressin release within the $16 \mathrm{~min}$ preceding the onset of $\mathrm{Ca}^{2+}$ stimulus (see controls shown in Figs 1-5). Pretreatment (see Experimental Procedures) of the permeabilized nerve terminals for 30 min with $100 \mathrm{nM}$ natural TeTxL almost completely blocked $\mathrm{Ca}^{2+}$ evoked vasopressin release (Fig. 1). Under these conditions vasopressin release was enhanced only approximately 1.3 -fold by calcium (see Figs 1-5). The recombinant WT light chain also blocked $\mathrm{Ca}^{2+}$ induced vasopressin release from the permeabilized nerve terminals (Fig. 1). After pretreatment with $100 \mathrm{nM}$ recombinant tetanus toxin light chain vasopressin release was increased 1.3-fold by
$10 \mu \mathrm{M} \mathrm{Ca}^{2+}$. Thus, when applied at a concentration of $100 \mathrm{nM}$, natural and recombinant tetanus toxin light chains are equally effective in blocking $\mathrm{Ca}^{2+}$ induced vasopressin release.

In the next step we carried out functional experiments with recombinant TeTxLs modified within the HELIH motif which is shared with a variety of zinc peptidases. ${ }^{30}$ We found that replacement of histidine 233 by cysteine or valine (mutants $\mathrm{H}^{233} \mathrm{C}$ or $\mathrm{H}^{233} \mathrm{~V}$ ) abolished the effect of the tetanus toxin light chain on $\mathrm{Ca}^{2+}$ induced vasopressin release (Fig. 1). Thus it appears that the biological activity of the TeTxL is linked to the presence of histidine 233 within the putative zinc binding HELIH motif.

If TeTxL acts as a zinc peptidase during the inhibition of vasopressin release from the terminals, removal of zinc was expected to abolish its activity. Medium B (see Experimental Procedures) used during the experiments, due to impurities in the chemicals, contains $2 \mu \mathrm{M}$ zinc (determined by atomic absorption spectroscopy) as well as $5 \mathrm{mM}$ EDTA and $0.5 \mathrm{mM}$ EGTA as chelating agents. Thus TeTxL is exposed prior to and during the experiments to EDTA and EGTA which bind zinc with high affinity. Free zinc in medium B, calculated as described ${ }^{24}$ is actually lower than $10 \mathrm{pM}$. Despite this low value, calcium induced vasopressin release was effectively blocked by natural and recombinant (WT) TeTxLs. To investigate a possible role of zinc in the action of the TeTx, we added a variety of other potent chelating agents for zinc. In the presence of both TeTx and $100 \mu \mathrm{M}$ of the zinc chelator diethyldithiocarbamate (DDC) vasopressin release was enhanced by $\mathrm{Ca}^{2+}$ approximately 2.3 -fold (from $67 \pm 1 \mathrm{pg}$ to

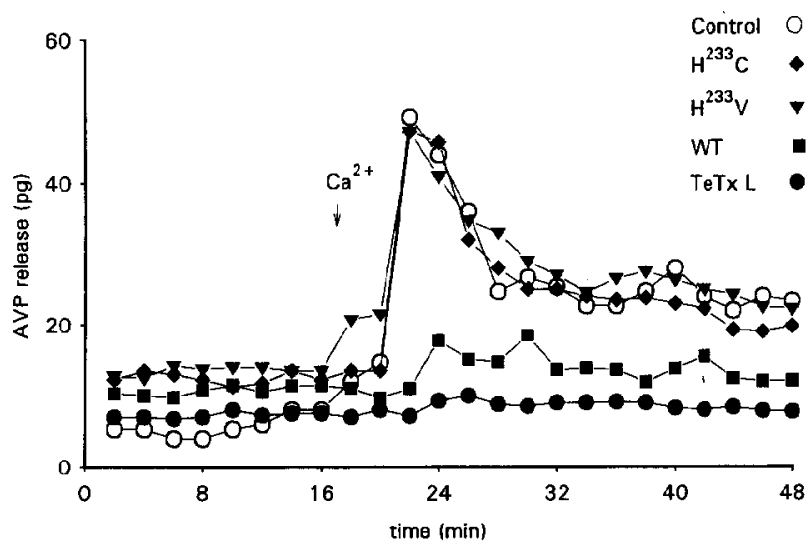

Fig. 1. Effect of natural and different recombinant TeTxL on vasopressin release from permeabilized nerve terminals. After permeabilization with streptolysin $\mathrm{O}$, the isolated nerve terminals were slowly perifused for $30 \mathrm{~min}$ (see Experimental Procedures) with medium B (control), $100 \mathrm{nM}$ natural (TeTxL) or recombinant TeTxL in medium $B$. After 16 min the nerve terminals were challenged with medium $B$ containing $10 \mu \mathrm{M}$ free $\mathrm{Ca}^{2+}$ (arrow). In the control experiments $\mathrm{Ca}^{2+}$ caused within $16 \mathrm{~min}$ an increase in vasopressin release from $46 \pm 3 \mathrm{pg}$ to $236 \pm 13 \mathrm{pg}$, mean of three experiments). The release of vasopressin was completely abolished by $100 \mathrm{nM}$ natural TeTxL (vasopressin release was enhanced by calcium from $69 \pm 10 \mathrm{pg}$ to $76 \pm 17 \mathrm{pg}$, mean of three experiments). Following pretreatment with $100 \mathrm{nM}$ WT recombinant TeTxL $81 \pm 11 \mathrm{pg}(n=7)$ vasopressin was released during the first 16 min which was increased by $10 \mu \mathrm{M} \mathrm{Ca}^{2+}$ only to $106 \pm 17 \mathrm{pg}$. Nerve terminals exposed to $100 \mathrm{nM}$ mutant $\mathrm{H}^{233} \mathrm{C}$ (histidine 233 replaced by cysteine) or $\mathrm{H}^{233} \mathrm{~V}$ (histidine replaced by valine) vasopressin release induced by calcium was similar in magnitude as in the control (mean of four experiments). 


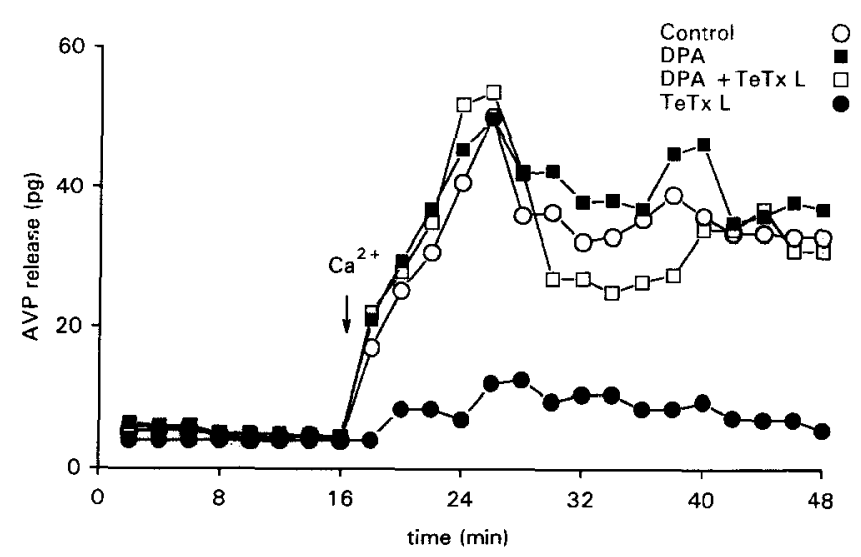

Fig. 2. DPA completely inactivates the TeTxL; DPA $(100 \mu \mathrm{M})$ alone does not modify calcium induced vasopressin release but the effect of TeTxL is almost completely abolished by DPA. Vasopressin release was similar in the presence and in the absence of DPA (values in brackets). It was enhanced by $\mathrm{Ca}^{2+}$ from $38 \pm 4 \mathrm{pg}(42 \pm 4 \mathrm{pg})$ to $268 \pm 24 \mathrm{pg}(306 \pm 36 \mathrm{pg})$. Vasopressin release is enhanced by $\mathrm{Ca}^{2+}$ in the presence of $100 \mathrm{nM}$ TeTxL alone from $32 \pm 1 \mathrm{pg}$ to $73 \pm 12 \mathrm{pg}$, and from $41 \pm 5 \mathrm{pg}$ to $287 \pm 48 \mathrm{pg}$ in the presence of both TeTxL and DPA. Vasopressin release in each group represents the mean of four experiments.

$152 \pm 12 \mathrm{pg}$ ) whereas, in the presence of the light chain alone, it was enhanced 1.3-fold (see above). DDC alone did not affect vasopressin release. These observations show that DDC, a strong chelating agent for zinc, diminished the effect of the TeTxL by approximately $50 \%$. By contrast, DPA, a chelating agent which displays high affinity for zinc and low affinity for calcium and magnesium, ${ }^{3}$ completely abolished the inhibititory effects of TeTxL when used at a concentration of $100 \mu \mathrm{M}$ (Fig. 2). The release of vasopressin induced by calcium, in the presence of DPA alone or in the presence of both DPA and tetanus toxin light chain was the same as in the control experiments. Thus it can be concluded that very potent agents chelating zinc such as DPA are required to prevent the TeTxL action in neurohypophysial nerve endings. We determined the amounts of zinc in the TeTxL preparation in the presence of $5 \mathrm{mM}$ EDTA and $0.5 \mathrm{mM}$ EGTA (medium B, see Experimental Procedures) and found that it contained 0.68 atoms zinc per mole TeTxL. Following treatment with $100 \mu \mathrm{M}$ DPA we measured 0.05 atoms zinc per mole TeTxL. This indicates that zinc is effectively removed from TeTxL by DPA, a chelating agent which blocks the effect of TeTxL on vasopressin release.

Incubation of permeabilized neurosecretosomes in the presence of the zinc peptidase inhibitor captopril $^{11,15}$ did not influence vasopressin release but captopril abolished the inhibitory effect of the TeTxL when applied together (Fig. 3). These data furthermore support the concept, that the TeTxL acts as a zinc peptidase during inhibition of exocytosis of secretory granules.

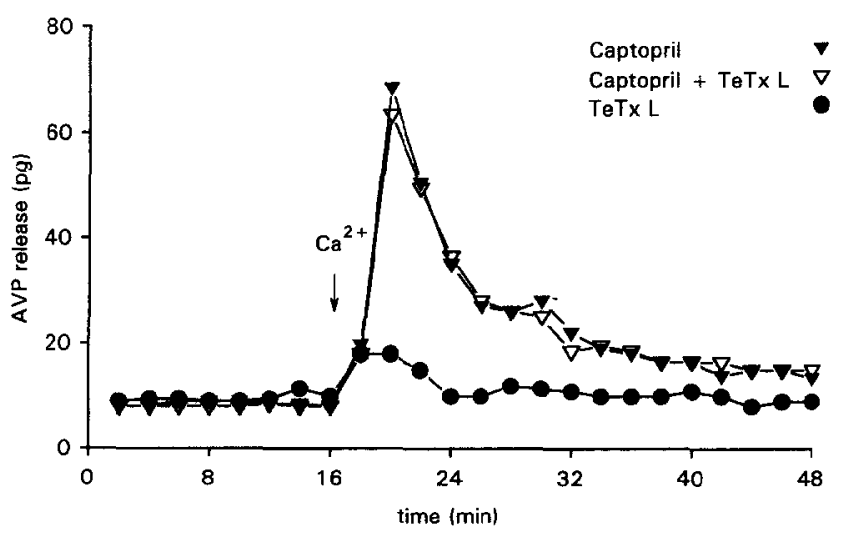

Fig. 3. Captopril abolishes the action of the TeTxL. While TeTxL almost completely blocks calcium induced vasopressin release, captopril, a potent inhibitor of zinc containing peptidases, abolished the effect of the neurotoxin light chain. In the presence of both $1 \mathrm{mM}$ captopril and $100 \mathrm{nM}$ tetanus toxin and in the control experiments performed in the presence of $1 \mathrm{mM}$ captopril alone (value in brackets) vasopressin release was enhanced by $\mathrm{Ca}^{2+}$ from $64 \pm 15 \mathrm{pg}(68 \pm 3 \mathrm{pg})$ to $265 \pm 23 \mathrm{pg}(227 \pm 19 \mathrm{pg})$. Vasopressin release is enhanced by $\mathrm{Ca}^{2+}$ in the presence of $100 \mathrm{nM}$ TeTxL alone from $77 \pm 6 \mathrm{pg}$ to $99 \pm 20 \mathrm{pg}$. Data are mean of four experiments of each group. 


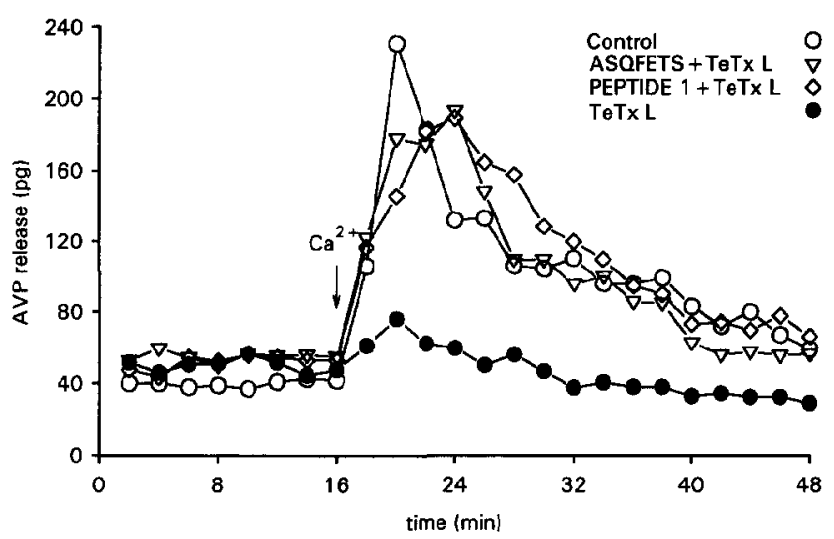

Fig. 4. Synthetic peptides corresponding to a motif present in synaptobrevin 1 and 2 abolish the effect of the TeTxL. $\mathrm{Ca}^{2+}$-induced vasopressin release was studied in the presence of $100 \mu \mathrm{M}$ ASQFETs or peptide 1 (DALQAGASVFESSAAKLKRK). While vasopressin release was blocked by $100 \mathrm{nM} \mathrm{TeTxL}$, this effect was prevented by ASQFETS and peptide 1. In the presence of both ASQFETS and TeTxL, vasopressin release was enhanced by $\mathrm{Ca}^{2+}$ from $438 \pm 24 \mathrm{pg}$ to $1130 \pm 46 \mathrm{pg}$. In the presence of both peptide 1 and TeTxL, vasopressin release was enhanced by $\mathrm{Ca}^{2+}$ from $416 \pm 17 \mathrm{pg}$ to $1205 \pm 97 \mathrm{pg}$. The peptides alone did not influence $\mathrm{Ca}^{2+}$ induced vasopressin release. Data are mean of four experiments of each group. Vasopressin release was enhanced by $\mathrm{Ca}^{2+}$ in the presence of $100 \mathrm{nM}$ TeTxL alone from $399 \mathrm{pg}$ to $449 \mathrm{pg}$ (two experiments) and in the absence of the TeTxL from $319 \pm 21 \mathrm{pg}$ to $1105 \pm 89 \mathrm{pg}$.

Co-incubation of the neurosecretosomes with the peptide ASQFETS $(100 \mu \mathrm{M})$, which contains the postulated site of synaptobrevin 2 cleaved by tetanus toxin in vitro, ${ }^{43}$ specifically abolished the inhibitory action of the TeTxL on vasopressin release (Fig. 4) but not on catecholamine release from adrenal chromaffin cells (Höhne-Zell et al., unpublished observations). Similar results were obtained with QFET (not shown) and a 20-mer (peptide 2) containing the same sequence (DALQAGASQFETSAAKLKRK, Fig. 5). However, a 20-mer corresponding to an analogous site of synaptobrevin 1 (peptide 1 : DALQAGASVFESSAAKLKRK) also prevented the effect of the TeTxL on vasopressin release (Fig.
4) indicating that peptides derived from both known members of the synaptobrevin family ${ }^{4}$ compete with the target of TeTxL within neurohypophysial terminals.

\section{DISCUSSION}

Link between tetanus toxin light chain, synaptobrevin and exocytosis of secretory granules

Recent evidence suggests that the inhibition of neurotransmitter release from synaptic vesicles by the tetanus toxin light chain may be causally linked to the cleavage of the synaptic vesicle membrane protein

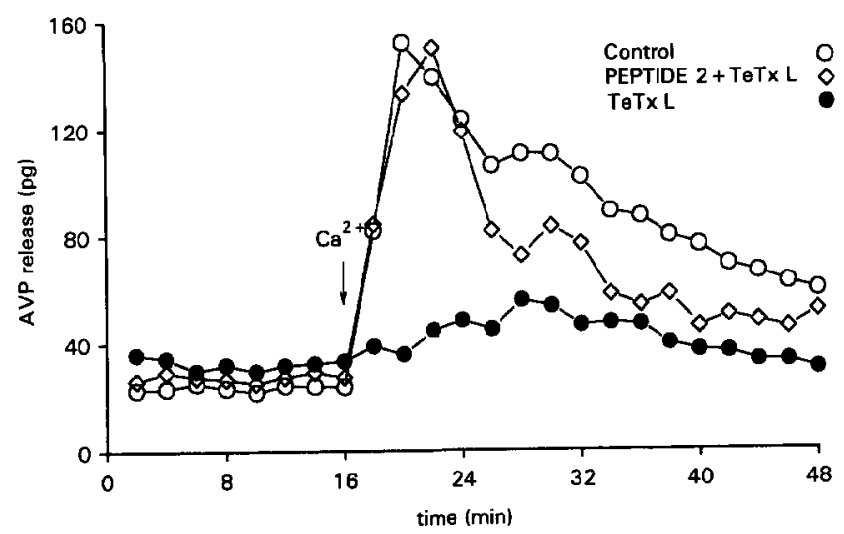

Fig. 5. A 20-amino acid peptides corresponding to a motif present in synaptobrevin 2 abolishes the effect of the TeTxL. While vasopressin release was blocked by $100 \mathrm{nM}$ TeTxL, this effect was prevented by $100 \mu \mathrm{M}$ peptide 2 (DALQAGASQFETSAAKLKRK). In the presence of both peptide 2 and TeTxL vasopressin release was enhanced by $\mathrm{Ca}^{2+}$ from $219 \pm 4 \mathrm{pg}$ to $800 \pm 25 \mathrm{pg}$. Peptide 2 alone did not influence $\mathrm{Ca}^{2+}$ induced vasopressin release. Data are mean of four experiments of each group. Vasopressin release was enhanced by $\mathrm{Ca}^{2+}$ in the presence of $100 \mathrm{nM}$ TeTxL alone from $260 \pm 13 \mathrm{pg}$ to $370 \pm 29 \mathrm{pg}$ (six experiments) and in the absence of the TeTxL from $190 \pm 9 \mathrm{pg}$ to $926 \pm 36 \mathrm{pg}$ (six experiments). 
synaptobrevin 2 and/or the covalent modification of the synaptic vesicle protein synapsin I. .1.22.32.43,44 $^{2}$ Synaptobrevin and other membrane proteins of secretory organelles are present exclusively in neural and endocrine cells but not in exocrine cells ${ }^{29,52}$ which appears to correlate with the observation that exocytosis by exocrine cells is insensitive to clostridial neurotoxins. ${ }^{48}$ Since we found that synthetic peptides containing the proposed synaptobrevin 2 cleavage site and the corresponding sequence of synaptobrevin 1 block the inhibition of vasopressin release by the TeTxL, synaptobrevins are probably critical for exocytosis and represent the prime target of tetanus toxin in neurohypophysial nerve endings.

Release of secretory products stored in synaptic vesicles and secretory granules from many, if not all, terminals of the central nervous system is inhibited by clostridial neurotoxins. ${ }^{26,36}$ In addition, data published on the inhibition of exocytosis from within nerve terminals or endocrine cells by the light chains of the neurotoxins imply that both synaptic vesicle and secretory granule membranes contain membrane proteins attacked by the neurotoxins' light chains. ${ }^{12,16,18,48-51}$ However, the membrane composition of synaptic vesicles and secretory granules is different $\mathrm{t}^{29,52}$ and only a few membrane proteins such as synaptotagmins have been reported to be present in both types of secretory vesicles. ${ }^{29,52,53}$ While synaptotagmin has consistently been found in adrenal chromaffin granules, ${ }^{23,34.46}$ positive $^{23}$ and negative ${ }^{39}$ reports exist for neurohypophysial secretory granules. Synaptotagmins like synaptobrevins and other secretory vesicle membrane proteins are apparently members of larger families differentially distributed in the CNS. ${ }^{20,25,58}$ Two reports suggest that some members of the synaptobrevin family are absent in adrenal and neurohypophysial secretory granules. ${ }^{5.33}$ However, the immunocytochemical techniques applied in these studies may not have been suitable to detect other members of the synaptobrevin family, which may subserve the same function. Indeed very recently a ubiquitous further member of the synaptobrevin family was detected which can be cleaved by tetanus toxin. ${ }^{35}$

Investigations of the mechanism by which clostridial neurotoxins inhibit exocytosis of secretory granules (this study) and synaptic vesicles ${ }^{32,43.44}$ suggest that synaptobrevins are essential components of the secretory machinery. TeTxL can be used as a tool to further dissect the molecular events during secretory vesicle docking and fusion and to find out how members of the synaptobrevin family participate in secretory granule and synaptic vesicle exocytosis. In this context it is interesting to note that synaptobrevins, in contrast to synaptotagmins, ${ }^{6,27}$ apparently interact via the intermediary of the $N$-ethylmaleimide-sensitive fusion protein (NSF) and the soluble NSF attachment protein (SNAP) complexes with cytoplasmic domains of acceptor membrane proteins of the plasmalemma. ${ }^{47}$
Mode of action of clostridial toxin light chains

Our data indicate that the TeTxL acts as a zinccontaining peptidase during inhibition of exocytosis of secretory granules. This conclusion is supported by the observations that (i) mutation of the histidine residue 233 of the TeTxL which constitutes the metal binding site, (ii) a chelating agent for $\mathrm{Zn}^{2+}$ (DPA), and (iii) an inhibitor of zinc peptidases (captopril), delete the inhibition of exocytosis by the neurotoxin light chain.

The observations documented in this study are compatible with the accumulated knowledge on the properties of clostridial neurotoxins. The amino acid sequences of five different types of botulinum neurotoxins and of tetanus toxin have only a few similar domains. $^{40}$ However, the motif HELIH (residues 233-237) of the light chains is conserved and is shared with typical zinc proteases. ${ }^{30}$ Indeed, binding of zinc to the light chain of tetanus toxin and botulinum $A$ toxin and to synthetic peptides containing the HELIH motif has recently been characterized ${ }^{45.59}$ (Niemann et al., unpublished observation). Preliminary data show that the histidine 233 mutants contain less zinc than the WT TeTxL (Yamaski et al., unpublished observation). The mutational analysis of the TeTxL carried out in the present study clearly indicates, that histidine 233 is of paramount importance for the biological activity, as are equivalent histidine residues in the metal binding site of other zinc enzymes. ${ }^{14,54}$ Surprisingly, injected mRNA encoding histidine 233 mutated TeTxL abolished neurotransmission in Aplysia neurons. ${ }^{7}$ The reason for this effect is at present unclear. However, the amounts of translated TeTxL in these neurons could be severalfold higher compared to the well-controlled concentrations used in permeabilized neurohypophysial nerve terminals. Binding of mutated TeTxL to substrates present on synaptic vesicles or modification of cytoskeleton/synaptic vesicle interactions ${ }^{21.22}$ could have caused the effect on release.

Depletion of zinc from the TeTxL by chelators abolished the inhibition of neurotransmitter release by Aplysia neurons. ${ }^{44}$ However, in previous investigations reported from this group ${ }^{1,2.16 .18 .48-51}$ as well as in the present investigation, TeTxL was kept in media with anionic chelating agents such as EGTA, EDTA or nitrilotriacetic acid prior to and during the release experiments (see Experimental Procedures). Using this protocol, the TeTxL was fully active, suggesting that zinc is not effectively removed by these chelating agents. Indeed the measurements reported in this study show that zinc remains bound to TeTxL under these conditions. Stronger complexing substances for zinc (such as DDC, used in this study) were also only partly effective but DPA which effectively removes zinc from TeTxL (this study) was very potent in deleting the effect of the TeTxL on vasopressin release. The requirement of a strong additional chelating agent for zinc in order to effectively block 
the action of the TeTxL suggests that the affinity of the light chain for zinc in media suitable to replace the intracellular fluid may be higher than reported ${ }^{59}$ The importance of zinc in the active site of TeTxL is further supported by the effectiveness of captopril, which via its sulfhydryl group complexes the zinc ion in the active center of metallopeptidases ${ }^{11,15}$ and inhibits the function of the neurotoxin in exocytotic release of vasopressin (this study), as well as the cleavage of synaptobrevin. ${ }^{32,43}$

\section{CONCLUSION}

In summary, we believe that TeTxL acts as a zinc peptidase within neurohypophysial nerve terminals and that its prime target in inhibiting secretory granule exocytosis is one or several members of the synaptobrevin family. It is suggested that neurohypophysial secretory granules and synaptic vesicles share these essential components in their exocytotic pathway.

Acknowledgements-This work was supported by a grant from the Deutsche Forschungsgemeinschaft (Gr 681), Actions integrees Franco-Allemands-Programme PROCOPE (to G.D. and M.G.). We thank Dr David Pow (Department of Physiology and Pharmacology, University of Queensland, Australia) and Dr Karl Schilling for critical reading of the manuscript. We thank Mrs J. Neckermann and Dr T. Ruppert (Ulm) for the synthesis and characterization of peptides, Mrs Ulrike Fröhlich and $\mathrm{Mr}$ Wolfgang Podschuweit for expert technical assistance and Mrs Brigitte Mader for preparing this manuscript. We are grateful to Dr Dieter Breitig and Mrs Lilo Zipfel and Angelika Kühnle for providing facilities for AVP radio-immunoassays and to Dr V. Krivan for zinc analyses by atomic absorption spectroscopy. We would like to thank Dr John Bicknell (Babraham, U.K.) for AVP antiserum and Dr K. D. Hungerer from the Behring Werke AG (Marbung, Germany) for the supply of sterile CI. tetani culture filtrate.

\section{REFERENCES}

1. Ahnert-Hilger G., Bader M. F., Bhakdi S. and Gratzl M. (1989) Introduction of macromolecules into bovine adrenal medullary chromaffin cells and rat pheochromocytoma cells (PC12) by permeabilization with streptolysin $\mathrm{O}$ : inhibitory effect of tetanus toxin on catecholamine secretion. J. Neurochem. 52, 1751-1758.

2. Ahnert-Hilger G., Weller U., Dauzenroth M. E., Habermann E. and Gratzl M. (1989) The tetanus toxin light chain inhibits exocytosis. Fedn Eur. biochem. Socs Lett. 242, 245248.

3. Anderegg G. (1960) 52. Pyridinderivate als Komplexbildner I. Pyridincarbonsäuren. Helv. Chim. Acta 43, 414-424.

4. Archer III B. T., Özçelik T., Jahn R., Francke U. and Südhof T. C. (1990) Structures and chromosomal localizations of two human genes encoding synaptobrevins 1 and 2. J. biol. Chem. 265, 17,267-17,273.

5. Baumert M., Takei K., Hartinger J., Burger P. M., Fischer von Mollard G., Maycox P. R., De Camilli P. and Jahn R. (1990) P29: a novel tyrosine-phosphorylated membrane protein present in small clear vesicles of neurons and endocrine cells. J. Cell Biol. 110, 1285-1294.

6. Bennett M. K., Calakos N. and Scheller R. H. (1992) Syntaxin: a synaptic protein implicated in docking of synaptic vesicles at presynaptic active zones. Science 257, 255-259.

7. Binz T., Grebenstein O., Kurazono H., Eisel U., Wernars K., Popoff M., Mochida S., Poulain B., Tauc L., Kozaki S. and Niemann H. (1992) Molecular biology of the I chains of clostridial neurotoxins. Zbl. Bakt. Suppl. 23, 56-65.

8. Bittner M. A., DasGupta B. R. and Holz R. W. (1989) Isolated light chains of botulinum neurotoxins inhibit exocytosis. J. biol. Chem. 264, 10,354-10,360.

9. Bittner M. A., Habig W. H. and Holz R. W. (1989) Isolated light chain of tetanus toxin inhibits exocytosis: studies in digitonin-permeabilized cells. $J$. Neurochem. 53, 966-968.

10. Bittner M. A. and Holz R. W. (1988) Effects of tetanus toxin on catecholamine release from intact and digitoninpermeabilized chromaffin cells. $J$. Neurochem. 51, 451-456.

11. Bull H. G., Thornberry N. A., Cordes M. H. J., Patchett A. A. and Cordes E. H. (1985) Inhibition of rabbit lung angiotensin-converting enzyme by $\mathrm{N} \alpha-[(\mathrm{S})$-1-carboxy-3-phenylpropyl] $\mathrm{L}$-alanyl-L-proline and $\mathrm{N} \alpha-[(\mathrm{S})-1-$ carboxy-3phenylpropyl]L-Lysyl-L-proline. J. biol. Chem. 260, 2952-2962.

12. Cazalis M., Dayanithi G. and Nordmann J. J. (1985) The role of patterned burst and interburst interval on the excitation-coupling mechanism in the isolated rat neural lobe. J. Physiol. 369, 45-60.

13. Cazalis M., Dayanithi G. and Nordmann J. J. (1987) Hormone release from isolated nerve endings of the rat neurohypophysis. J. Physiol. 390, 55-70.

14. Coleman J. E. (1992) Zinc proteins: enzymes, storage proteins, transcription factors, and replication proteins. A. Rev. Biochem. 61, 897-946.

15. Cushman D. W., Cheung H. S., Sabo E. F. and Ondetti M. A. (1977) Design of potent competitive inhibitors of angiotensin-converting enzyme. Carboxyalkanoyl and mercaptoalkanoyl amino acids. Biochemistry 16, 5484-5491.

16. Dayanithi G., Ahnert-Hilger G., Weller U., Nordmann J. J. and Gratzl M. (1990) Release of vasopressin from isolated permeabilized neurosecretory nerve terminals is blocked by the light chain of botulinum A toxin. Neuroscience 39, $711-715$.

17. Dayanithi G. and Nordmann J. J. (1989) Chloride and magnesium dependence of vasopressin release from rat permeabilized neurohypophysial nerve endings. Neurosci. Lett. 106, 305-309.

18. Dayanithi G., Weller U., Ahnert-Hilger G., Link H., Nordmann J. J. and Gratzl M. (1992) The light chain of tetanus toxin inhibits calcium dependent vasopressin release from permeabilized nerve endings. Neuroscience 46, 489-493.

19. Eisel U., Reynolds K., Riddick M., Zimmer A. and Niemann H. (1993) Tetanus toxin light chain expression in Sertoli cells of transgenic mice causes alterations of the actin cytoskeleton and disrupts spermatogenesis. Eur. molec. Biol. Org. J. 12, 3365-3372.

20. Elferink L. A., Trimble W. S. and Scheller R. H. (1989) Two vesicle-associated membrane protein genes are differentially expressed in the rat central nervous system. J. Cell Biol. 19, 11,061-11,064. 
21. Facchiano F., Benefenati F., Valtora F. and Luini A. (1993) Covalent modification of synapsin I by a tetanus toxin-activated transglutaminase. J. biol. Chem. 268, 4588-4591.

22. Facchiano F. and Luini A. (1992) Tetanus toxin potently stimulates tissue transglutaminase. J. biol. Chem. 267, $13,267-13,271$.

23. Fournier S. and Trifaró J.-M. (1988) A similar calmodulin-binding protein expressed in chromaffin, synaptic, and neurohypophyseal secretory vesicles. J. Neurochem. 50, 27-37.

24. Föhr K. J., Warchol W. and Gratzl M. (1993) Calculation and control of free divalent cations in solutions used for membrane fusion studies. Meth. Enzymol. 221, 149-157.

25. Geppert M., Archer III B. T. and Südhof T. C. (1991) Synaptotagmin II. A novel differentially distributed form of synaptotagmin. J. biol. Chem. 266, 13,548-13,552.

26. Halpern J. L., Habig W. H., Trenchard H. and Russell J. T. (1990) Effect of tetanus toxin on oxytocin and vasopressin release from nerve endings of the neurohypophysis. $J$. Neurochem. 55, 2072-2078.

27. Hata Y., Davletov B., Petrenko A. G., Jahn R. and Südhof T. C. (1993) Interaction of synaptotagmin with the cytoplasmic domains of neurexins. Neuron 10, 307-315.

28. Högy B., Dauzenroth M.-E., Hudel M., Weller U. and Habermann E. (1992) Increase of permeability of synaptosomes and liposomes by the heavy chain of tetanus toxin. Toxicon 30, 63-76.

29. Jahn R. and De Camilli P. (1991) Membrane proteins of synaptic vesicles: markers for neurons and neuroendocrine cells; tools for the study of neurosecretion. In Markers for Neural and Endocrine Cells (eds Gratzl M. and Langley K.) pp. 25-92. VCH-Verlagsgesellschaft, Weinheim.

30. Jongeneel C. V., Bouvier J. and Bairoch A. (1989) A unique signature identifies a family of zinc-dependent metallopeptidases. Fedn Eur. biochem. Socs Lett. 242, 211-214.

31. Kurazono H., Mochida S., Binz T., Eisel U., Quanz M., Grebenstein O., Wernars K., Poulain B., Tauc L. and Niemann H. (1992) Minimal essential domains specifying toxicity of the light chains of tetanus toxin and botulinum neurotoxin type A. J. biol. Chem. 267, 14,721-14,729.

32. Link E., Edelmann L., Chou J. H., Binz T., Yamasaki S., Eisel U., Baumert M., Südhof T.. C., Niemann H. and Jahn R. (1992) Tetanus toxin action: inhibition of neuratransmitter release linked to synaptobrevin proteolysis. Biochem. biophys. Res. Commun. 189, 1017-1023.

33. Matteoli M., Navone F., Haimann C., Cameron P. L., Solimena M. and De Camilli P. (1989) Secretory organelles of neurons and their relationship to organelles of other cells. Cell Biol. int. Rep. 13, 981-992.

34. Matthew W. D., Tsavaler L. and Reichardt L. F. (1981) Identification of a synaptic vesicle-specific membrane protein with a wide distribution in neuronal and neurosecretory tissue. J. Cell Biol. 91, 257-269.

35. McMahon H. T., Ushkaryov Y. A., Edelmann L., Link E., Binz T., Niemann H., Jahn R. and Südhof T. C. (1993) Cellubrevin: a ubiquitous tetanus-toxin substrate homologous to a putative synaptic vesicle fusion protein. Nature 364 , 346-349.

36. McMahon H. T., Foran P., Dolly J. O., Verhage M., Wiegant V. M. and Nicholls D. G. (1992) Tetanus toxin and botulinum toxins type $\mathbf{A}$ and $\mathrm{B}$ inhibit glutamate, $\gamma$-aminobutyric acid, aspartate, and met-enkephalin release from synaptosomes. $J$. biol. Chem. 267, 21,338-21,343.

37. Mochida S., Poulain B., Eisel U., Binz T., Kurazono H., Niemann H. and Tauc L. (1990) Exogenous mRNA encoding tetanus or botulinum neurotoxins expressed in Aplysia neurons. Proc. natn. Acad. Sci. U.S.A. 87, 7844-7848.

38. Mochida S., Poulain B., Weller U., Habermann E. and Tauc L. (1989) Light chain of tetanus toxin intracellularly inhibits acetylcholine release at neuro-neuronal synapses, and its internalization is mediated by heavy chain. Fedn Eur. biochem. Socs Lett. 253, 47-51.

39. Navone F., Di Gioia G., Jahn R., Browning M., Greengard P. and De Camilli P. (1989) Microvesicles of the neurohypophysis are biochemically related to small synaptic vesicles of presynaptic nerve terminals. J. Cell Biol. 109, $3425-3433$

40. Niemann H. (1991) Molecular biology of clostridial neurotoxins. In Sourcebook of Bacterial Protein Toxins (eds Alouf J. E. and Freer J. H.), pp. 299-344. Academic Press, New York.

41. Nordmann J. J. and Dayanithi G. (1988) Release of neuropeptides does not only occur at nerve terminals. Biosci. Rep. 8, $471-483$.

42. Sanger F., Nicklen S. and Coulson A. R. (1977) DNA sequencing with chain-terminating inhibitors. Proc. natn. Acad. Sci.U.S.A. 74, 5463-5467.

43. Schiavo G., Benfenati F., Poulain B., Rossetto O., de Laureto P. P., DasGupta B. R. and Montecucco C. (1992) Tetanus and botulinum-B neurotoxins block neurotransmitter release by proteolytic cleavage of synaptobrevin. Nature 359, $832-835$.

44. Schiavo G., Poulain B., Rossetto O., Benfenati F., Tauc L. and Montecucco C. (1992) Tetanus toxin is a zinc protein and its inhibition of neurotransmitter release and protease avtivity depends on zinc. Eur. molec. Biol. Org. J. 11, $3577-3583$.

45. Schiavo G., Rossetto O., Santucci A., DasGupta B. R. and Montecucco C. (1992) Botulinum neurotoxins are zinc proteins. J. biol. Chem. 267, 23,479-23,483.

46. Schmidle T., Weiler R., Desnos C., Scherman D., Fischer-Colbrie R., Floor E. and Winkler H. (1991) Synaptin/synaptophysin p65 and SV2: Their presence in adrenal chromaffin granules and sympathetic large dense core vesicles. Biochim. biophys. Acta 1060, 251-256.

47. Söllner T., Whiteheart S. W., Brunner M., Erdjument-Bromage H., Geromanos S., Tempst P. and Rothman J. E. (1993) SNAP receptors implicated in vesicle targeting and fusion. Nature 362, 318-324.

48. Stecher B., Ahnert-Hilger G., Weller U., Kemmer T. P. and Gratzl M. (1992) Amylase release from streptolysin O permeabilized pancreatic acinar cells. Effects of calcium, GTPyS, cAMP, tetanus toxin and botulinum A toxin. Biochem. J. 283, 899-904.

49. Stecher B., Gratzl M. and Ahnert-Hilger G. (1989) Reductive chain seperation of botulinum A toxin-a prerequisite to its inhibitory action on exocytosis in chromaffin cells. Fedn Eur. biochem. Socs Lett. 248, 23-27.

50. Stecher B., Hens J. J. H., Weller U., Gratzl M., Gispen W. H. and De Graan P. N. E. (1992) Noradrenaline release from permeabilized synaptosomes is inhibited by the light chain of tetanus toxin. Fedn Eur. biochem. Socs Lett. 312, $192-194$. 
51. Stecher B., Weller U, Habermann E., Gratzl M. and Ahnert-Hilger G. (1989) The light chain but not the heavy chain of botulinum A toxin inhibits exocytosis from permeabilized adrenal chromaffin cells. Fedn Eur, biochem. Socs Lett. 255, 391-394.

52. Südhof T. C. and Jahn R. (1991) Proteins of synaptic vesicles involved in exocytosis and membrane recycling. Neuron 6, 665-677.

53. Trifaró I.-M., Fournier S. and Novas M. L. (1989) The p65 protein is a calmodulin-binding protein present in several types of secretory vesicles. Neuroscience $29,1-8$.

54. Vallee B. L. and Falchuk K. H. (1993) The biochemical basis of zinc physiology. Physiol. Rev. 73, 79-105.

55. Wegenhorst U., Gratzl M., Föhr K. J, and Ahnert-Hilger G. (1989) Millimolar concentrations of free magnesium enhance exocytosis from permeablized rat pheochromocytoma (PC 12) cells. Neurosci. Lett. 106, 300-304.

56. Weller U., Dauzenroth M.-E., Meyer zu Heringdorf D. and Habermann E. (1989) Chains and fragments of tetanus toxin. Separation, reassociation and pharmacological properties. Eur. J. Biochem. 182, 649-656.

57. Weller U., Mauler F and Habermann E. (1988) Tetanus toxin: biochemical and pharmacological comparison between its protoxin and some isotoxins obtained by limited proteolysis. Naunyn-Schmiedeberg's Arch. Pharmac. 338, 99-106.

58. Wendland B., Miller K. G., Schilling J. and Scheller R. H. (1992) Differential expression of the p65 gene family. Neuron 6, 993-1007.

59. Wright J. F., Pernollet M., Reboul A., Aude C. and Colomb M. G. (1992) Identification and partial characterization of a low affinity metal-binding site in the light chain of tetanus toxin. J. biol. Chem. 267, 9053-9058.

(Accepted 29 September 1993) 